STATE OF ALASKA

DEPARTMENT OF NATURAI, RESOURCES

\title{
METAMORPHIC ROCKS OF TOKLAT-TEKLANIKA RIVERS AREA, ALASKA
}

By

W.G. Gilbert and Earl Redinan

GEOLOGIC REPORT 50
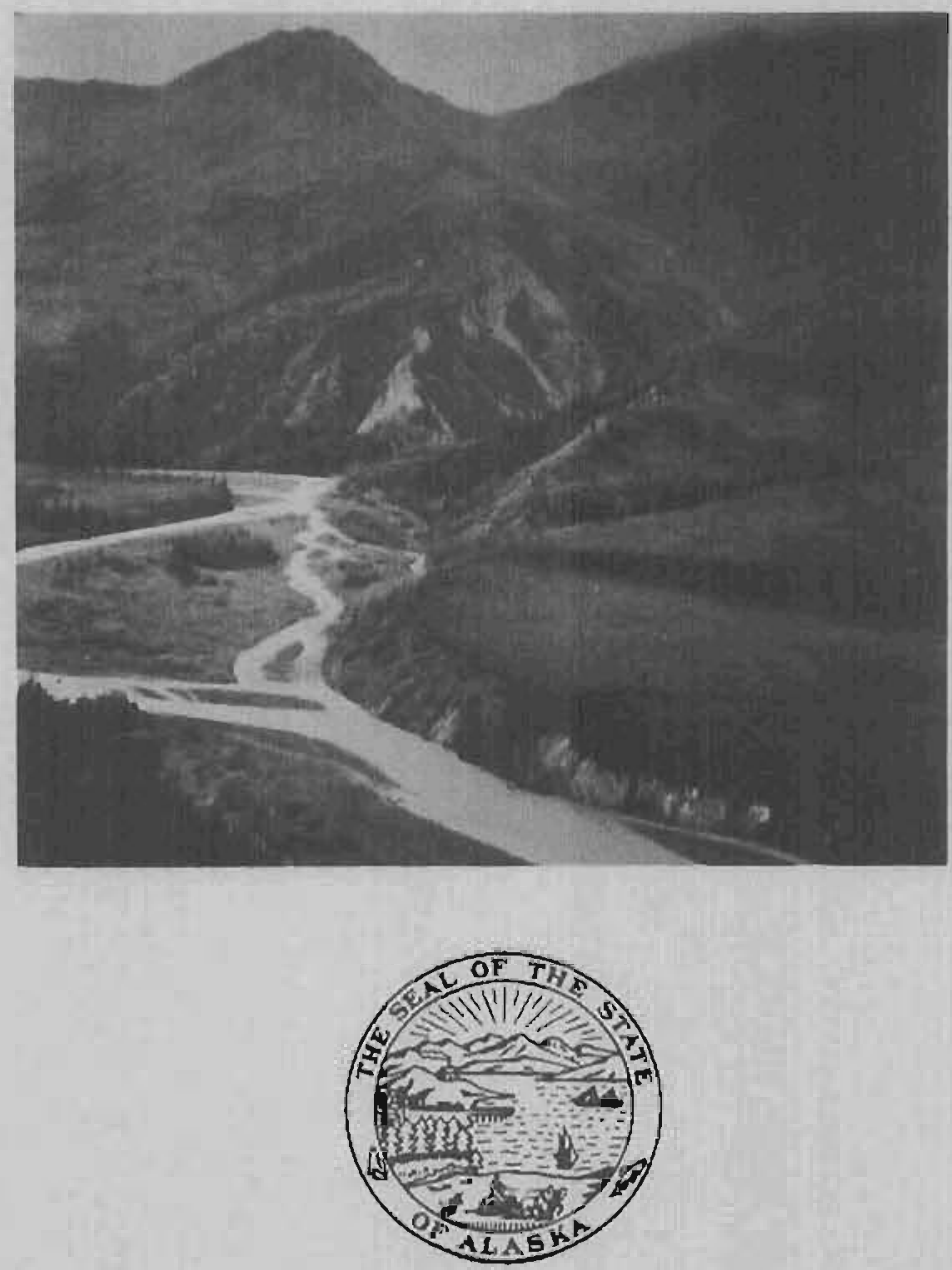

Publliked by

IJVISION OF GEOLOGICAL \& GEOPHYSICAL SUIZVEYS

COI_LE.GE, ALASKA

1977 
STATE OF ALASKA

Jay S. Hammond, Governor

Robert E. LeResche, Commissioner, Dept. of Natural Resources

Ross G. Schaff, Slate Geologist

Cover: Loohing southwest across East Fork Toklat River along the Wyoming Hills fault.

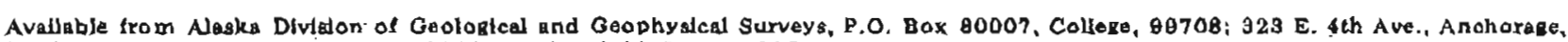
99601; P.O. Box 7488, Ketchlkan, 99801; and Pouch M. Junequ, 99811- 
ERRATA

The following errata are for the Alaska Division of Geological $\varepsilon$ Geophysical Surveys Geologic Report 50, "Metamorphic rocks of ToklatTeklanika Rivers area, Alaska," by W.G. Gilbert and Earl Redman, which was recently sent your organlzation.

"Page 11. The lower "S 2 " in figure 12 should read "S,."

- Page 13. The second reference should read:

Bundtzen, T.K., Smith, T.E., and Tosdal, R.M., 1976, Progress report: Geology and mineral deposits of the Kantishna Hills, Alaska: Alaska Div. Geol. and Geophys. Surveys Open-File Rept. $98,80 \mathrm{p}$.

- Plate 1. Heavy lines on cross sections caused by printing error. 


\section{CONTENTS}

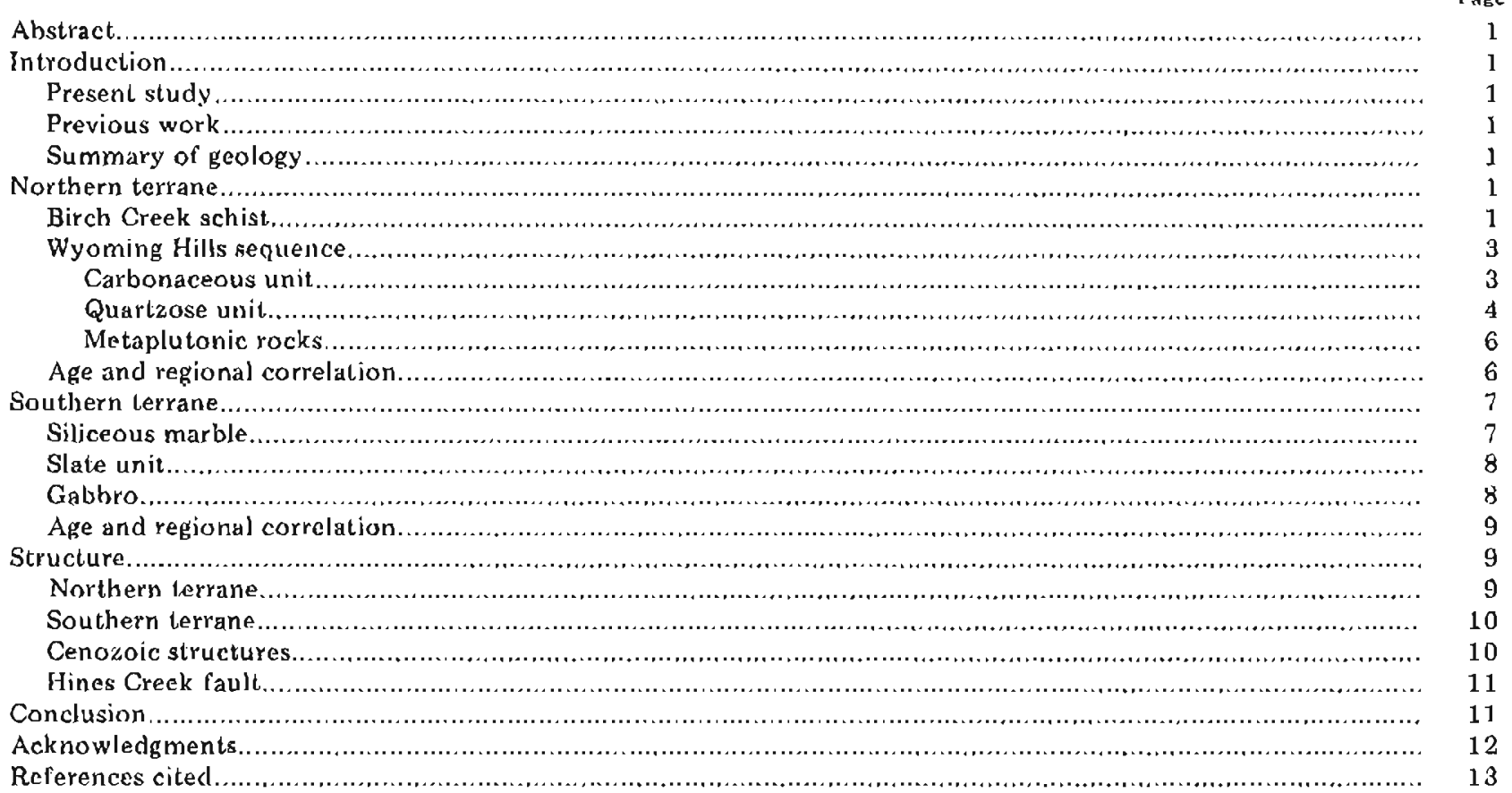

\section{ILLUSTRATIONS}

Figure 1. Metamorphic rocks north of Denali Faull system in west-central Alaska Range, and location of this study.....

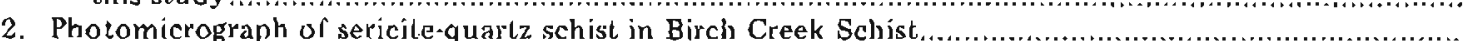

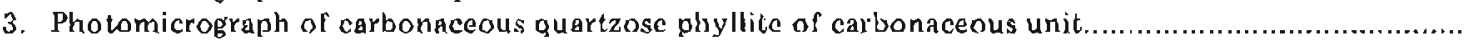

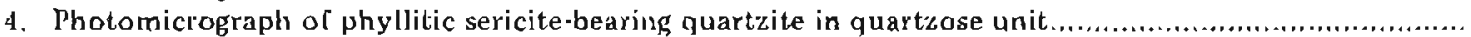

5. Photomicrograph of melafelsite showing relict resorbed phenocrysts of quartz and microcline............

6. Metamorphosed hypabyssal quartz diorite exhihiting well-preserved relict igneous tex ture..................

7. Photomicrograph of siliceous marble.

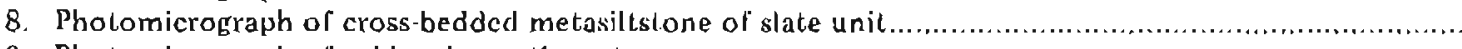

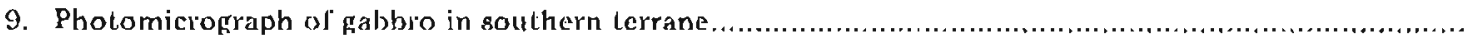

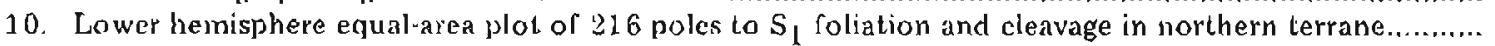

11. Folded Birch Creek Sch ist, showing prominent $\mathrm{F}_{2}$ folds.....

12. Photomicrograph of sericite-quartz phyllite of Wyoming Hills sequence showing $S_{1}$ foliation and crosscuting $\mathrm{S}_{2}$ cleavage.....

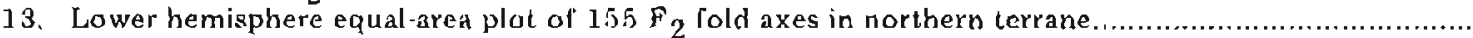

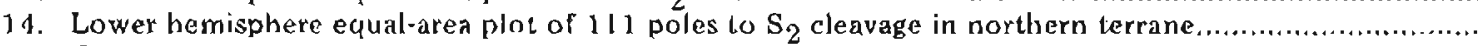

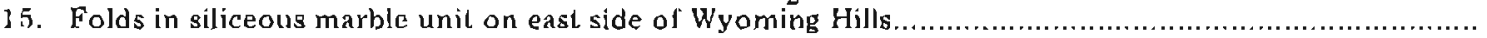

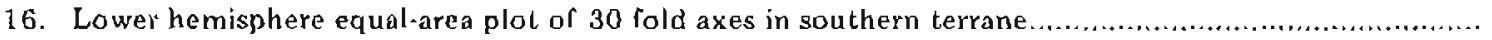

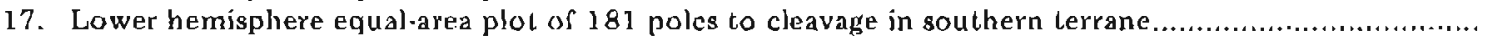

18. Looking west at trace of Hines Creek lault in Wyoming Hills......

\section{TABLES}

Table 1. Geochemical analyses from two metalelsiles and one metaplutonic rock in the Wyoming Hills............

2. Fossils. 


\title{
MI'T'AMORPHIC, ROC,KS OF' 'TOKLAT'TEKI,ANIKA RIVERS AREA, ALASKA
}

\author{
By W. (i. Gilherl" and Fiart Redman ${ }^{2}$
}

\section{ABSTRARIT}

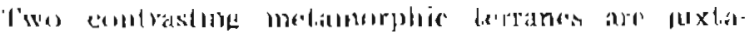

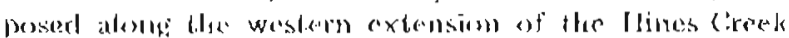

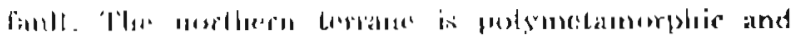

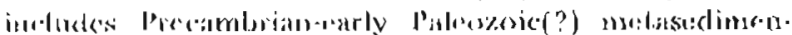

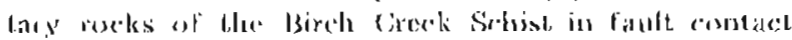

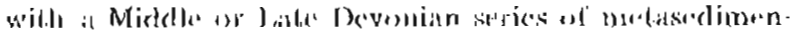

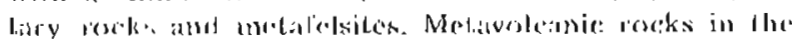

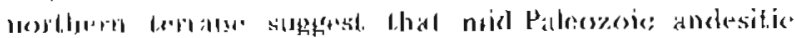

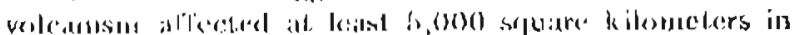
antrial Sliatia.

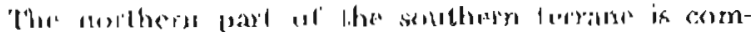

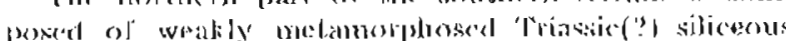

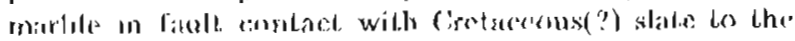

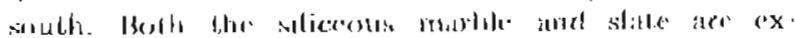

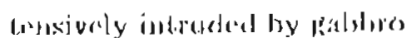

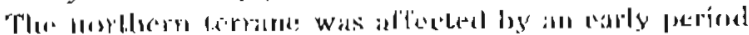

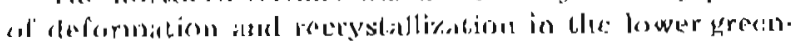

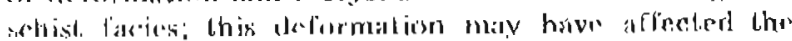

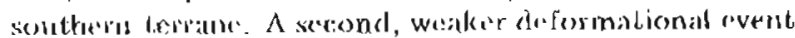

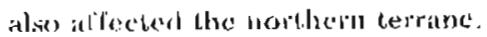

\section{IN'TRODUC"IIUN}

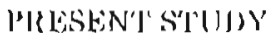

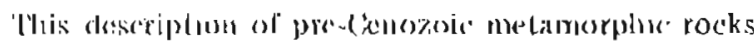
sulworn llow l'eklanika and l'oklat rivers in the westcondial Nlaskat Range (lïg. 1) is pat of an ongosing

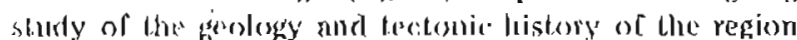
(Cilhert. 1975; Cilheyt and Redman, 1975: Gilbert, Firrenl, and flurner, 1978). l'ield investigations of the areat were condueled during the summers of 1973 and 197\%. Pelrographic cxamination was made of 63 thin sections, and moclal compositions were dolermined by counting of 100 points per thin section.

\section{PRJVIOUIS WOIRK}

Melamorphic: rocks in the study area were liust mapped by Broulss (1911) as belonging to the Birch Creek Schist, the Tatina Group, and the Tomzana Gromp. Further mapping by Capps (1919) restricted the rocks in the nothern terrane of this study to the Birch Crack Schist and the Tomona Group, and assigned the rocks in the southern terrane to the Tatima Group. Subsequont roconnaissance sludies have referred

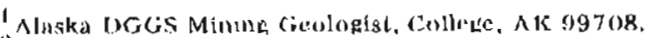

${ }^{2}$ Geologlsl, Cities Service Mineral Corp., Anolhorake, $\Lambda$ K 99501.
}

wo the rocks: in the southern termane as modifferentiatent

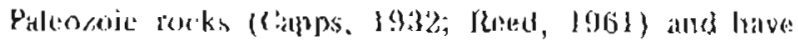

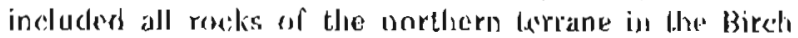
Creck Schist (Gapps, 1910; Rerd, 1961: Hirkman, (971).

\section{SIIMMNRX (OF G}

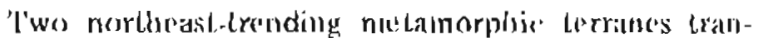

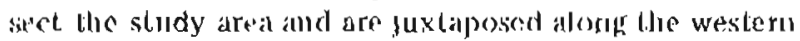
extension of the llines (irese strand of the J)enali foulf xystem. 'lhe nerthern terrane is composed of (wo polymetamorphic rock units: an older series of metil. sedimentury rocks, which is part of the Birch Croek schist, and a youmfer series of earbonaceous plyyllices, pelitir and psammitic phyllites and quartzites, and metafelsites. Hossil evidence suggestis that the age of the younger sfries is, in part, Middle or Jate Devonian. 'l'he northern part of the southern tertane is composied of weakly melanorphosed siliceous marbles in fault contact with slate and metasandstone to the south. both units in the southern terrane are extensively in. truded by gabbro.

\section{NORTHERN T'ERRANE}

\section{BIRCH CIEHK SCHIST}

Micaceous quartzite and sericite-quartz schist of the Birch Creek schist are present in a northeast-trending band, 3 to $5 \mathrm{~km}$ (kilometers) wide, which exiends from the northeast corner of the Healy C- 6 quadrangle to the wesl side of the last lork Toklat River canyon (pl. 1). Scatlered exposures are also found on the northwest side of lire Wyoming Hílls. 'Tlis belt of rocks is part of a more extensive terrane that continues east and north (Capps, 19.19; Wahrhaftig, 1968: Wegner, 1972; and Hickman, 1974) and west (Capps. 1919; Morrison, 1961) (fig. 1). From a dislance the rocks are light gray wo tan and form prominent tors by differential weathering along joints and cleavage. A conspicuous orangeweathered yone marks the Birch Creek Schist for 30 to $50 \mathrm{~m}$ (meters) beneath the overiying Coal-Bearing Group.

Quartz- and mica-rich banding in quartzite, schist, ard phyllite may in parl represent original compositional layering, but this layering reflects two periods of metamorphism. The compositional layering defines a prominent foliation $\left(S_{1}\right)$, which displays prominent 


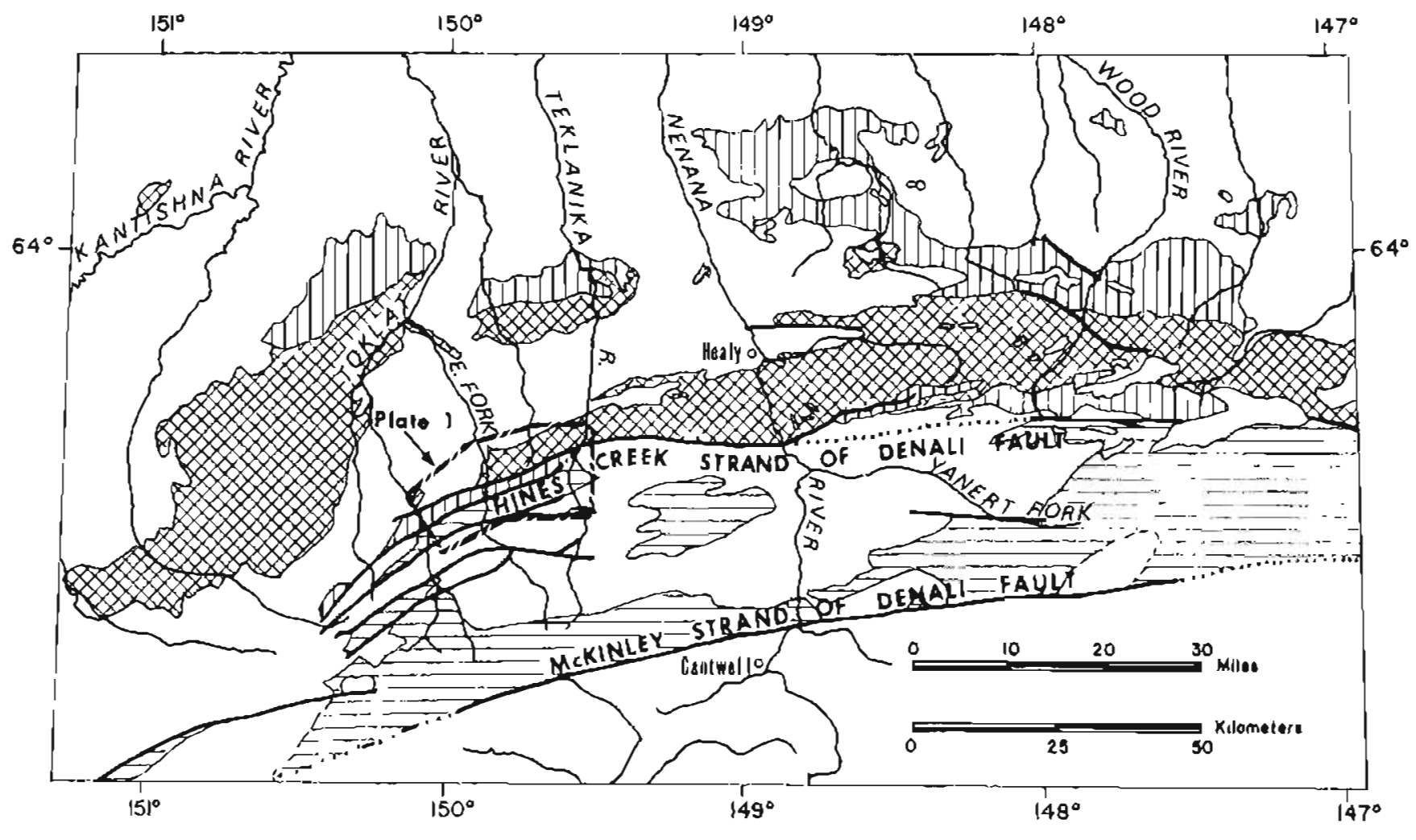

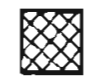

Primarily polyme Lumorphic lower Paleozoic and Precambrian metasedimentary rocks

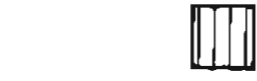

Primurily palymelamorphle mid-Paleozole metaredimotary and metavolcanic rocks

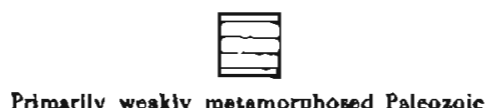

Primerily weskly metamorphosed Paleozoic
and Mesozaic sedimentary and votcanic rocks

Figure 1. Metamorphic rocks north of Denali Fault system in west-central Alaska Range, and location of this study.

folds $\left(F_{2}\right)$ and is cut by woll-developed cleavage $\left(S_{2}\right)$. Locally, the schistose rocks of the Birch Creek Schist grade to phyllite, and the unit is similar in composition and deformational style to quartz-rich portions of the Wyoming Hills sequence ( $p .3$ ). It is difficull to differenliate the two rock units where they are in conlact. The Birch Creek Schist, however, is more homogenous, is slightly more schistose, and exhibits better developed $F_{2}$ folding and $S_{2}$ cleavage than the Wyoming Hills sequence.

'I'he dominant rock type in the Birch C'reek Schist is a gray-, pink-, or green-weathering white micaceous quartzite (70 percenl) that lends to split into layers $1.0 \mathrm{~mm}$ (milsimeter) to $1.0 \mathrm{~cm}$ (centimeter) thick. Gray sericite-quartz schist (20 percent) (fig. 2) and light. to medium-green chlorite-actinolite schist and phyllite (10 percent) are olher common lithologies. Chlorite-actinolite 'schisl and phyllite are more abundant (15 percent) in the eastern and southern parts of the outcrop beit than in the nortl and west ( 5 percent). In a 1-km-wide belt just north of the Wyoming Hills lault near the Teklanika River (pl. 1), chlorite-actinolite schist and phyllite and chlorite-sericite quartz sehist make up 30 percent of the exposures. Black carbonaceous phyllite, light-green orthogneiss, and tightly folded layers of medium- Lo light-gray marble up to $1.0 \mathrm{~m}$ thick are minor coinponencs of the Birch Creek Schist.

Micaceous quartzitc and sericite-quartz schist in the Birch Creek Schist are metamorphosed quart\%-rich pelitic and psammitic sediments. These rocks are characterized by the presence of quart\% + sericite \pm albite \pm chlorite \pm biotite \pm lourmaline \pm lie-poor epidote \pm trenolite \pm calcite. Incipient biotite, derived from chlorile and sericite in liliree of the samples, suggests that these rocks have reaclied the lower part of the greenschist facies (fig. 2). Xenoblastic quartz (38.81 percent) and albite (0.8 percent) up to $1.0 \mathrm{~mm}$ long are dimensionally oriented parallel to the foliation and generally form layers as thick as $4.0 \mathrm{~mm}$. Sericite and muscovite ( 5.41 percent), chlorte $(0.8$ percenl), and biotite (0-1 percent) form discontinuous wavy bands up to $3.0 \mathrm{~mm}$ lhick that parallel quartz-rich layers. Fe-poor epidote (0-18 percent) locally forms irregular aggregates in quartz-rich layers. Calcite (0-4 percent) occurs as either irregular inasses or as idio. 
blastic rhombohedra as long as $0.3 \mathrm{~mm}$. Tourmaline generally occurs as minor scattered subidioblastic crystals randomly oriented in both the qually and mica-rich layers (fig. 2). Sphene, zircon, iron oxidrs, and tremolite are rare accessory minerals.

Minor green schistose metabasite within the Birch Creek Schist contains quarlz + chlorile + epidote + actinclite, and a light-green orthogneiss (metadiorite?) seen in the southeast comer of NEl/4, sec. 1, T. $14 \mathrm{~S}$, R. 11 W. contains quartz + albite + chlorite + Fe-poor cpidote + tremolite. Xenoblastic quartz and albite form bands parallel to layers of sheatlike and fibrous tremo. lite or actinolite, and chlorite. Subidioblaslic epídote occurs throughout these rocks.

All examined specimens of the Birch Creek Schist were completely recrystallized during the first recorded metamorphic event ( $\left.F_{1}\right)$. Qumiz, albite, sericite, chlorite, biolite, epidote, and tremolite-actinolite formed synkinemalically and segregated into compositional bands, whereas epidole, lourmaline, and calcite are common postkinematic minerals. The second melamorphic event $\left(\mathrm{F}_{2}\right)$ developed prominent folds and slip cleavage $\left(S_{2}\right)$ in the Birch Creek Schist, buc produced no major thermal effects.

The Birel Creek Schist is in fault conlack with the Wyoming Hills sequence (pl. 1). The Cantwell Forination and the Coal-Bearing Group unconformably overlie the Birch Creek Schist in the northern and westem parts of the study area, respectively. The contact between the Birch Creek Schist and the Nenana Gravel east of the Teklanika River is not exposed, but because the conlact lollows the rastward projection of the Wyoming Hills fault, lie contacl is mapped as a fault. Tertiary(?) igneous rocks cut the Birch Creek Schist; dikes of Tertiary(?) quartz porphyry are Cound in no olher pre. Tertiary unit in the study area.

\section{WYOMING HILLS SEQUENCE}

Carbonaceous quartzose phyllite, marble, quartzose phyllite, and quartzite form a belt $4-6 \mathrm{~km}$ wide across the northern half of the Healy C-6 quadrangle and eastern part of the Mt. Mckinley C-1 quadrangle (pl, 1). These rocks atre rvell exposed in the southern part of the wyoming Hils, and are here informally referred to as the Wyoming Hills sequence. These rocks can be subdivided into at loast two different units, a lower car. bonaceous unit and an upper quartzose unit. The Wyoming Hills seguence is tightly folded, faulted. and structurally thickened; in the Wyoming Hills, it has a structural thickness of about $1,600 \mathrm{~m}$.

The Wyoming Hills sequence is polymetamorphic with crossculting fold axes, foliation, and cleavage re. tlecting at leist two deformational events. The first deformational exut recrystallized the sequence in the lower greenschist facies and produced isoclinal folds and a well.developed axial plane schistosity $\left\{S_{1}\right)$ defined uy micaceous minerals or carbonaceous material or

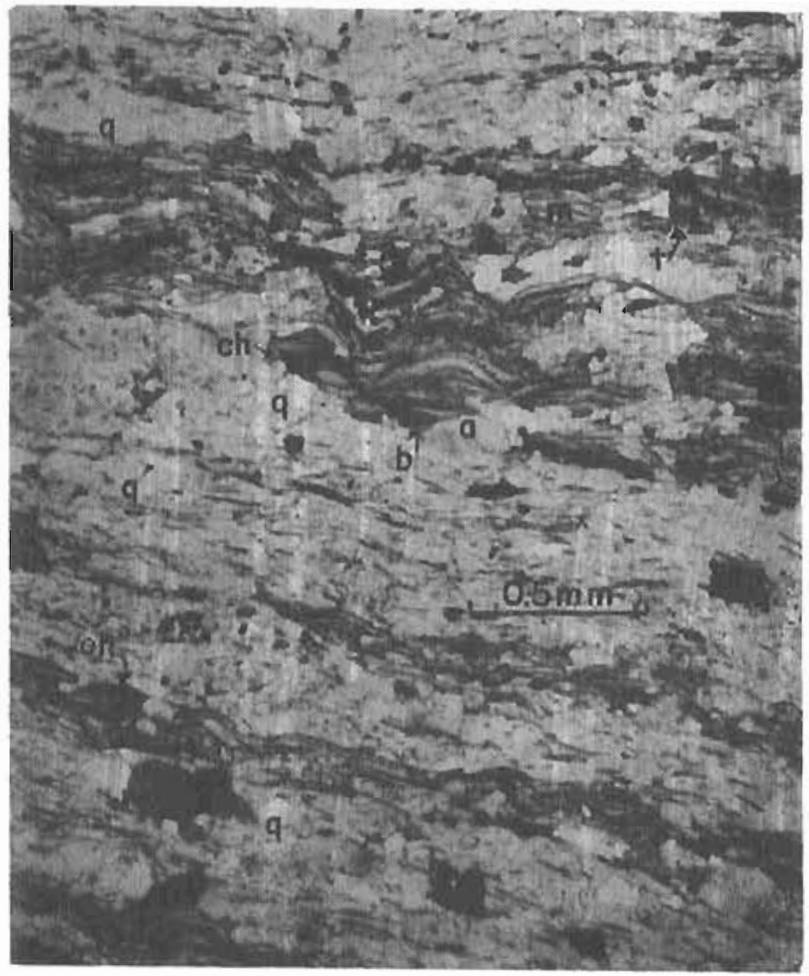

Figure 2. Pholomicrograph uf sericile-quarlz schist in Birch Creek Schist; $q=q u a r t z, m=$ muscovite, $c h=$ chlorite, $b=$ biotite, $a=a l b i t e, ~ b=$ tourmaline. Plane light.

both. A slip cleavage $\left(S_{2}\right)$ along which shearing and incipient recrystallization have taken place is moderately well developed parallel to the axial surfaces of second. generation folds $\left(\mathrm{F}_{2}\right)$.

\section{CARBONACEOUS UNIT}

The carbonaceous unit is composed of carbonaceous quartzose phyllite and quartzose phyllile and crops out in three areas: 1 ) in a northwest-dipping band in the Wyoming Hills, 2) on the limbs of a syncline extending for 5 kim northeast of the Fast. Fork Toklat River, and 3 ) in a band $1.0 \mathrm{~km}$ wide and $3.0 \mathrm{~km}$ long trending west from the Teklinika River in the northeast comer of the sludy area (pl. 1). In the Wyoming Hills the unit has an apparent structural thickisess of about $1,130 \mathrm{~m}$. There the dominant rock type is a dark-gray, pyrite-bearing, iron-stained carbonaceous quartzose phyllite (fig. 3). In this area discontinuous intercalations of light-green fissile quartzose phyllite, 6 to $20 \mathrm{~m}$ thick, form 10 percent of the unit.

East of the East Fork Toklat River, the carbonaceous unit is more quarlz-rich and eontains about 50 percent carbonaceous quartzose phyllite, 35 percent. light-gray quartzite and quartzose phyllite, and 15 percent marble. Light.gray weathering, dark-gray fossiliferous marble 
lavers are concentrated near the top of the carbonaceous unit and are mapped separately where they predominate. Individual layers of marble, carbonaceous plyyllite. and quartzose phyllite are approximately $30 \mathrm{~m}$ thick and pinch and swell along strike.

In the carbonaceous phyllite xenoblastic quarty (50-80 percent) is the most abundant constituent. commonly forming a mosaic of erystals less than 0.01 $\mathrm{mm}$ across. Alternating hyers of quartz and of finely divided carbonaceous material ( $5-15$ percent) and quartz are up to $3.5 \mathrm{~mm}$ thick (fig. 3). Ribbon-textured quarts is found in the carbonaceous bands and probably was formed by intrafolial shearing. Where $S_{2}$ slip cleavage is well developed. carbonaceous material is commonly realigned parallel to cleavage. Subidioblastic laths of sericite and muscovite (3-35 percent) and chlorite $\left(0-5\right.$ percent) lying parallel to $\mathrm{S}_{1}$ are found throughout the rocks but tend to be concenirated in carbonaceous layers. Ldioblastic pyrite cubes less than $0.15 \mathrm{~mm}$ across or subidioblastic carbonate-apatite crystals less than $0.02 \mathrm{~mm}$ long locally form up to 3 percent of these rocks. The quartzose phyllite and quartzite in the carbonaceous unit are similar to those

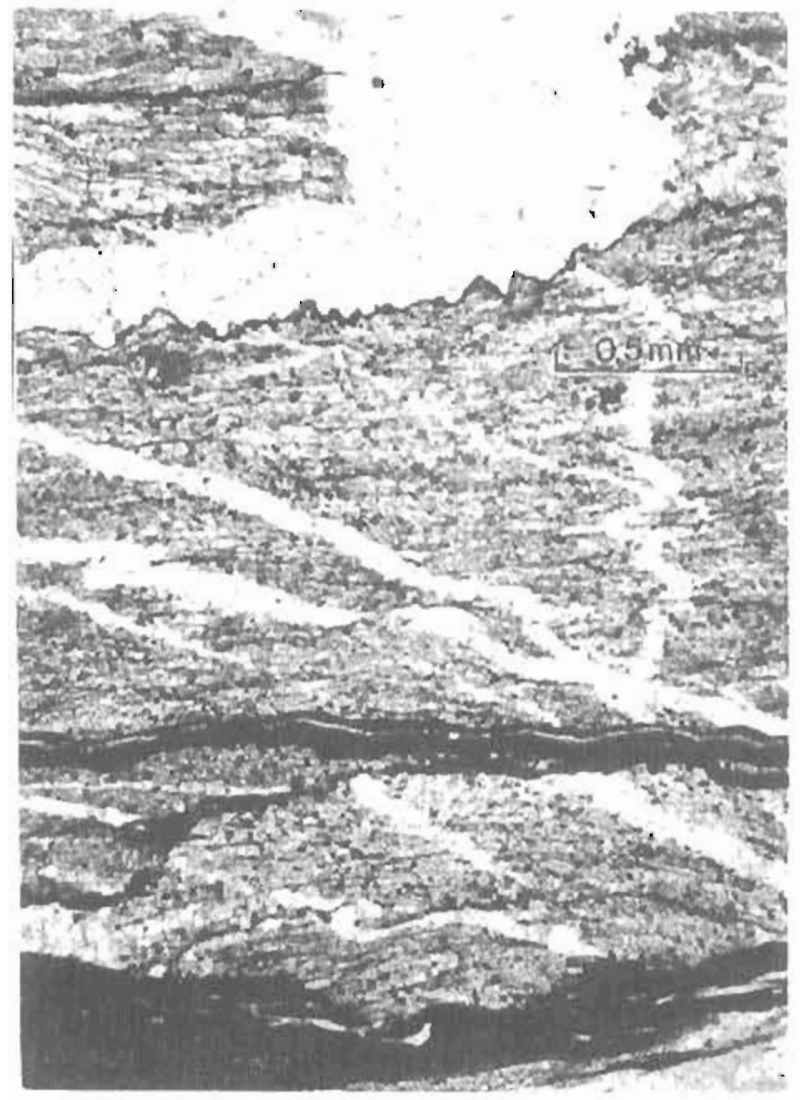

Figure 3. Photomicrograph of carbonaceous quartzose phylite of earbonaceous unit. Dark layers are carbonaceous material, light, layers are quartz, and dark spots are carbonate-apatite. Plane light. described for the quarlzose unit Rocks of the car bonaceous unit are probably manly metamorphosed organic-rich siliceous shales.

The original stratigraphic relationship between the carhonaceous unit and the quartzose unit is not clear. but because the carbonaceous unit appears to underlie the quartzose mit, it is considered to be the older of the l,wo. In the western portion ol the map area, the carbonaceous unit is in contact with the siliceous marble unit along the northwest-dipping Hines Creek fault.

\section{QUARTZOSE UNIT}

Quartzose phyllite and quarizite of the quartzose unit crop out in an irregular northeast-trending band up to $4 \mathrm{~km}$ wide extending from the west bank of the Teklanika River through the Wyoming Hills (pl. 1). The unit probably continues west of the Tokbat River. The maximum structural thickness of the unit, just west of the 'Teklanika River, is about $2,700 \mathrm{~m}$. In the Wyoming Hills the lower and middle part of the quarlzose unit consists of 35 percent light-gray quartzite, 30 percent light-gray quartz phylite, 10 percent. light-green quartz phyllite, 10 percent light-green quartzite, and 10 percent carbonaceous phyllite: lightegray fine-grained marble, light-green orthogneiss, and metaconglomerate whe also present but make up less than 5 percent of the unit. In the Wyoming Hills the apper 100 $m$ of the quartzose unit is composed of black carbonaceous quartzose phyllite similar te that found in the carbonaceous unit.

Between the Teklanika and East Fork Toklat Rivers, the quartzose unit contains 40 percent light-gray phyllitic quart.zite, 25 percent light-gray (graphitic) quartzose phyllite, 20 percent light-gray to black quartzite, and 10 percent light-green (chloritic) quartzose phyllite: discontinuous bavers of lipht-gray-weathering dark-gray silty marble up to $15 \mathrm{~m}$ thick make up the remaining 5 percent of the unit. Individual layers of marble and phyllite can be traced for up to $3 \mathrm{~km}$. The quartzoșe unil, is composed of two distinct rock types, psammitic and pelitic melasedimentary rocks and metafelsite. Light-gray rocks are generally metasedimentary rocks and lighl-green quartzile and phyllite are generally metarelsite.

Quartzites are composed primarily of quartz ( $80-95$ percent) and sericite and muscovite ( $4-7$ percent) (fig. 4). Quartz generally forms a mosaic of xenoblas.tie strained erystals that are less than $0.05 \mathrm{~mm}$ long and which have a directional orientation. Quarl\% porphyroblasts 0.3-0.8 $\mathrm{mm}$ long are also present. Recrystallization and annealing of quartz is complete. In one quartzite specimen the quartzose groundmass contains 7 percent albite. Sericite forms both as scat. tered idioblastic laths and as discontinuous layers up to $10.0 \mathrm{~mm}$ long and $0.2 \mathrm{~mm}$ thick parallel to $S_{1}$. Common trace constituents are tourmaline, chlorite, corbonaceous malter, iron oxides, apatite, zircon, and calcite. The 
Table 1. Geochemical analyses from two metafelstes, 73WER-64 and 73WER-240, and one metaplutonic rock 73 WER-243, in the Wyoming Hills. (Rapid ruck lechnique by Siryline Labs, Inc. Wheat Ridge, CO.J

\begin{tabular}{|c|c|c|c|}
\hline \multirow[b]{2}{*}{ Oxide } & \multicolumn{3}{|c|}{ Sample (Wt.\%) } \\
\hline & 73WER-64 & 73WER-240 & 73WER-243 \\
\hline $\mathrm{S}_{1} \mathrm{O}_{2}$ & 76.4 & 72.6 & 48.0 \\
\hline $\mathrm{TiO}_{2}^{2}$ & 0.12 & 0.50 & 1.ij \\
\hline $\mathrm{Al}_{2} \mathrm{O}_{3}$ & $12, \overline{3}$ & 14.1 & 15.3 \\
\hline $\mathrm{Fe}_{2} \mathrm{O}_{3}{ }^{1}$ & 1.7 & 2.0 & 10.7 \\
\hline $\mathrm{MnO}$ & 0.015 & 0.021 & 0.15 \\
\hline $\mathrm{MgO}$ & 0.92 & 1.5 & 7.3 \\
\hline $\mathrm{CaO}$ & 1.1 & 0.12 & 6.3 \\
\hline $\mathrm{Na}_{2} \mathrm{O}$ & 2.3 & 1.8 & 1.5 \\
\hline $\mathrm{K}_{2} \mathrm{O}$ & 1.9 & 4.3 & 3.7 \\
\hline $\mathrm{P}_{2} \mathrm{O}_{5}$ & 0.02 & 0.08 & 0.05 \\
\hline $\mathrm{H}_{2} \mathrm{O}+$ & 1.5 & 2.2 & 4.2 \\
\hline $\mathrm{H}_{2} \mathrm{O}-$ & 0.4 & $<0.1$ & $<0.1$ \\
\hline
\end{tabular}

1Tata! Fe.

mineralogy of quartzose phyllites is similar to che quartzites excol that the phyllites contaiti more sericite $(4.35$ percent) and finely divided carbonaceous material (up to 50 percent) and less quartz (15.60 percent).

Light-green blastoporphyritic melafelsite intervals, now in tercalated with quartzose melasedimentany rocks, were probably originally rhyolites or rhyodaciles (lable 1). In these rocks quartz (30-65 percent), sericile and muscovite $(0.57$ percent), albite $(0-15$ percen () , and microcline (0.15 percent) are the most abundant constituents (fig, 5). Quartz is present is relicl phenocrysts $2.0 .7 .0 \mathrm{~mm}$ across, commonly exhibiting $\beta$ quartz outlines and resorption channels, sel in a ricrystallized quartzo-feldspath ic groundmass. Albite is both scaltered in the groundmass and forms xenoblastic porphyro. blasts, which are commonly poikiloblastic with quartz inclusions. Nicrocline is present as irregular relict phenocrysts up to $3.0 \mathrm{~mm}$ across and occasionally ex. hibits replacement perthite and resorption tectures. Sericite forms layırs up $101.0 \mathrm{~mm}$ thick consisting of laths less than $0.004 \mathrm{~mm}$ long. Sericite layers generally define $S_{1}$ layerng, although they are occasionally re oriented along $S_{2}$ slip cleavage. Subidioblastic-xeno blastic epidote forms postkinematic and synkinematic clusters and individual laths from plagioclase. Occa sionally calcite has replaced plagioclase or has formec secondary veinlets. Scattered xenoblastic aggregates of iron oxide minerals (0-4 percent), together witi zircor and sphene, are common accessory minerals.

One green phyllite inlerval, probably a melabasalt conlains metamorphic quartz + albile + actinolite chlorite + epidolc. In this inturval flattened quartz anc plaspioclase with actinolite and chlorite define a pro. minum $S_{1}$ foliation, and xenoblastic epidote porpliyroblasts up to $0.4 \mathrm{~mm}$ lony have grown aind rotated in actimolit.'-rich layers. Finely disseminaled opaclue minerals are present enroughout the rock, and calcite veinlets fill postlkinemalic fraclures.

Metasedimentary rocks of the quartzose unil and the Birch Creek Schist have very similar mineralogy and metamorphic history. The major difference between the units is a slightly less well-developed metamorphic fabric and the prisence of a large meta-igneous component in the Wyoming Hills sequence.

The original contact bilween the quartyose unit and

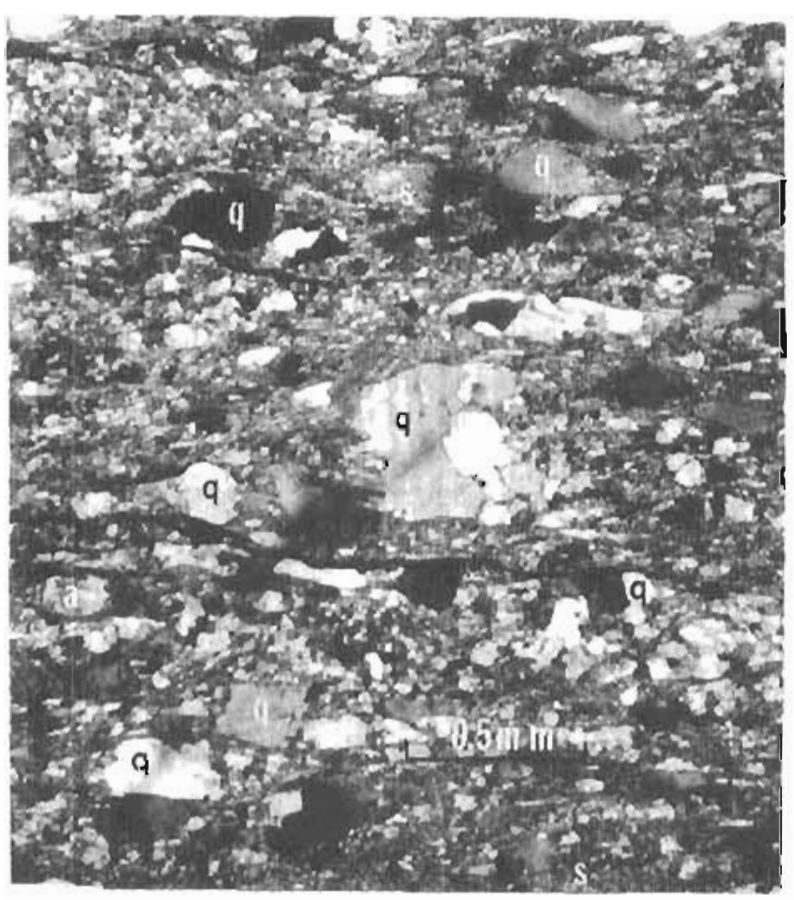

Figure 4. Photomicrograph of phyllitic sericite-bearing quarline in quartzose unit: $q=$ quartz, $s=$ sericite, $a=a l b i t e$. Crossed nicols. 


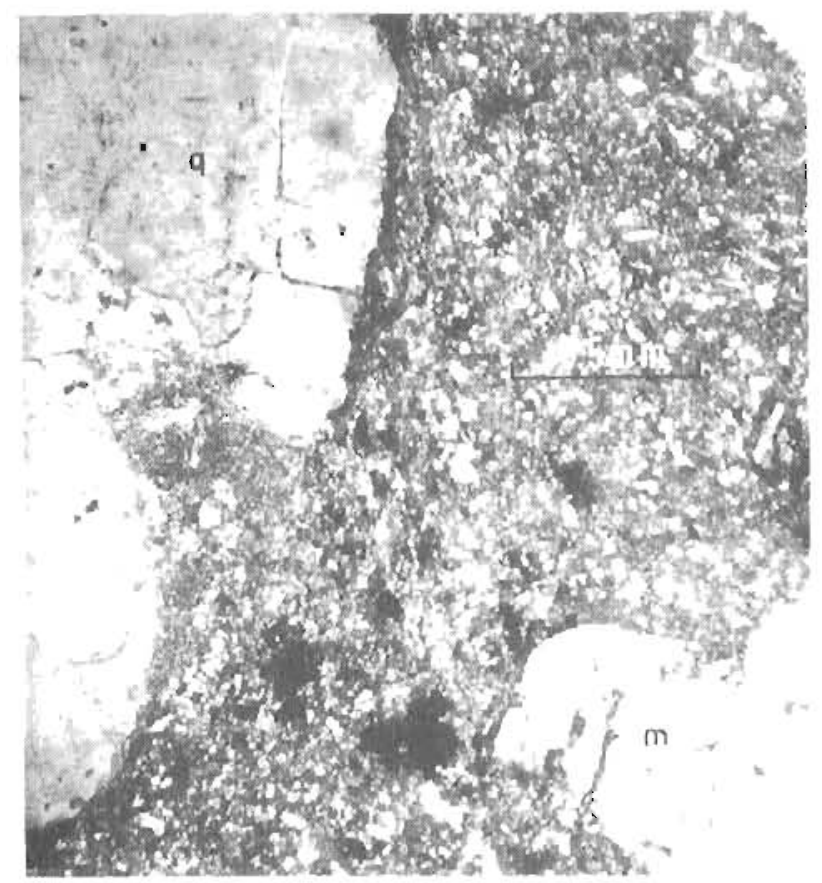

Figure 5. Photomicrograph of metafelsite showing re. lict resorbed phenocrysts of quartz and microcline; $q=q u a r t z, m=$ microcline. Crossed nicols.

the carboracesus unit has been blurred by inelamurphism, but is apparenlly a depositional rontact or uncesnformity. 'l'he quartzose unit is in fault eonlact with the Birch Creek Schist on the north and with the siliceuus matrble unil of the southem terrane on the south (pl. 1).

\section{METAPLUTONIC ROCKS}

Several melamorphosed intrusions, ranging from hornblende quartz diorile to augite gabbro, cut the Wyoming Hils sicuence (table 1 ). The rocks generally contain quartz + albile + sericite + tremolite + epidote $*$ chlorite tealcite. Blastoporphyritic hornblende quartz dinriti near peak 4836 indicates that some of the plutons were shallow and hypabyssal $(p l, 1)$. There relict phenocrysls of homblende and plagioclase are set in a fine-grained quarlzo-felds)athic groundmass (fig. 6).

In the melaplutonic rocks xenoblastic chlorite (2-20 percent) and (tomolite (5.15 percent) have generally formed from humblende or augite. Chlorite commonly has replaced homblende or augite and is replaced in turn by tremolite. Tremolite has also replaced plagioclase and commonly defines the $S_{1}$ foliation. Xenoblastic abjite porphyroblasts (10-35 percent) are generally derived from relict phenocrysts or groundmass. Xeno. blastic epidote (1-5 percent) forms scattered crystals and clusters that commonly replace mafic minerals or plagioclase. Fine subidioblastic laths of sericite $(5-25$ percent) and calcite are common in plagioclașe. Relict iron oxides (ilmenite?) are generally partly alcered to leucoxene.

\section{AGE AND REGIONAL, CORRELATION}

The northern terranc contains rocks of Precambrian to Late Devonian age and is part of the crystalline basement complex underlying interior Alaska between the Denali and the Tintina fault systems (King, 1968). Rocks of the Birch Creek Schist have yielded no fossils in the map area and their age is tentatively considered Precambrian to early Paleozoic. Fossils were found at four localities in marble beds at or near the top of the carbonaceous unit in the Wyoming Hills sequence. The ages of these fossils, summarized in table 2 , irdicate that the carbonaceous unit is Middle or Late Devonian in age. Rocks of the quartzose unit appear to overlie the fossil-bearing unit and are probably Late bevonan or Mississippian in age.

East of the map area is a series of schistose meta felsite and metasedmentary rocks, and greenstones which are, in part, Devonian in age (Wahrhaftig, 1968; Hickman and Craddock, 1976). These rocks form a belt up to $7.0 \mathrm{~km}$ wide that extends from Montana Creek, $8.0 \mathrm{~km}$ northeast of Mckinley Park station, for at least $70 \mathrm{~km}$ to the east (fig. 1). This belt contains lithologies similar to those Cound in the Wyoming Hills sequence, including a Inwer carbonaceous member (Hickman, 1971). The Wyoming Hills sequence was probably once continuous with this bell.

The Keevy Peals Fomation and Tolallanilia Sclisit. are metaniorphosed clastic metasedimentary rocks, Luff,

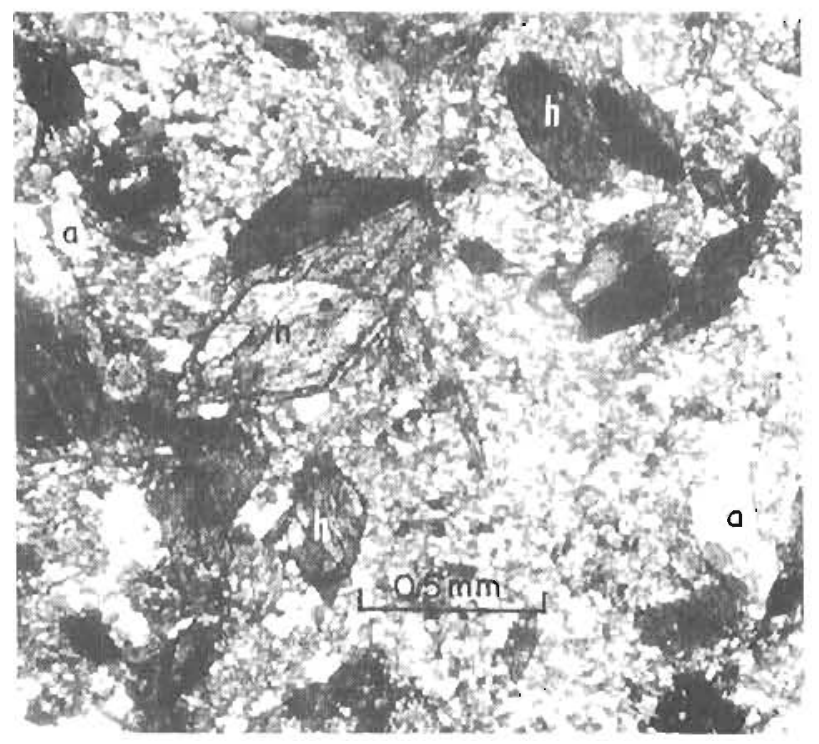

Figure 6. Meldmurphosed hypabyssal quarti diorite exhibiting well-preserved relict igneous texture: $h=$ hornblende, a=albite. Crossed nicols. 
felsite, basalt, and carbonate, and form a discontinuous bell across the north slope of the central Alaska Range (fig. 1) (Wahrhaftig, 1968). These rocks are of uncertain mid-Paleozoic and older age and unconformably or tec. tonically overlie the Birch Creek Schist (Capps, 1940; Wahrhaftig, 1968; Bundtzen, 1976; Gilbert, 1977), In detail. however, the Totatlanika Schist appears to be more pyroclastic than the Wyoming Hills sequence and its upper part, at least, is more weakly metamorphosed.

This study expands the area of known míd-Paleozoic volcanic rocks in the central Alaska Range. If the present areas where these rocks now occur were once continuous, the area of mid-Paleozoic andesitic volcanism may have covered more than $5,000 \mathrm{~km}^{2}$.

\section{SOUTHERN TERRANE}

\section{SILICEOUS MARBLE}

A lolded sequence of thin-bedded dark-pray siliceous marble, phylfitic marble, and carbonaceous slate can be traced from the eastern boundary of the map area east of Teklanika campground in the western boundary of the map area in the Wyoming Hills (pl. 1). The outcrop belt is 1.5 to $3.0 \mathrm{~km}$ wide, and in the Wyoming Hills the sequence reaches a struclural thickness of $3,300 \mathrm{~m}$.

Individual fine-grained marble beds are 0.1 to $5.0 \mathrm{~m}$ thick, weather to a yellowish-brown rough surface, and display fine laminations. Occasional black chert modules are scattered throughout the marble. The phyllitic marble is highly fissile and usually occurs in beds 0.01 to $4.0 \mathrm{~m}$ thick; beds of $10 \mathrm{~m}$ or more are uncommon. Whereas the marble is resistant and stands out in bold relief, phyllitic marble weathers to loose clebris. In some areas concordant quartz layers form up to 40 percent of the section, and crosscutting sparry calcite veins and veinlets are common. Near the margins of gabbro and diorite intrusions, both marble and phyllite are silicified, except in the Wyoming Ifills, where very coarse-grained marble surrounds intrusions. The unit has been weakly metamorphosed by a single metamorphic event and displays prominent cleavage and isoclinal folds.

The siliceous marble unil is composed of calcite crystals ( $53-83$ percent) and quarlz grains $(5.29$ percenl) 0.01 to $0.50 \mathrm{~mm}$ across, and lesser amountis of carbonaceous material $(2.20$ percenl $)$ and sericite (0-3 percent) (ng. 7). Eissility increases as quartz and carbonaceous material increase and calcite decreases. Quurlz grains exhibit angular to subangular detrital outlines and occasionally very incipient recrystalliza. tion, whereas calcite is xemoblastic. The texture of the rock varies from a mosaic of equidimensional calcite and quartz in siliceous marble, which locally exhibits cine bedding laminations marked by concentrations of heavy minerals (acnerally magnetite, with minor zircon),

Table 2. Fossils

\section{Northern Terrane}

\begin{tabular}{|c|c|c|}
\hline $\begin{array}{l}\text { Locality } \\
\text { (plate 1) }\end{array}$ & Fossils & Age \\
\hline $1^{\text {a }}$ & $\begin{array}{l}\text { Possible Amphipera sp. } \\
\text { Disphyllum? sp. } \\
\text { cl. Grypophyllum sp. }\end{array}$ & Devonian, probably Middle Devonian \\
\hline $2^{4}$ & Disphyllum? sp. & $\begin{array}{l}\text { Probably Middle or Eadly Late Devonian } \\
\text { (Frasnian) }\end{array}$ \\
\hline $3^{a}$ & $\begin{array}{l}\text { Disphyllum? sp. } \\
\text { Plitlipsastraea sp. } \\
\text { Tabulophyllum sp. }\end{array}$ & Late Devonian (Frasnian) \\
\hline $4^{\mathrm{b}}$ & $\begin{array}{l}\text { Echinoderm clastic particles, } \\
\text { some of which are pelmete. } \\
\text { zoan columnels }\end{array}$ & Ordovician to Permian or possibly younger. \\
\hline \multicolumn{3}{|c|}{ Southern Termane } \\
\hline $5^{c}$ & Conodants & Triassic \\
\hline $6^{d}$ & $\begin{array}{l}\text { Inoceramus cf, concentricus } \\
\text { (possibly allochthonous) }\end{array}$ & Mid-Cretaceous \\
\hline
\end{tabular}

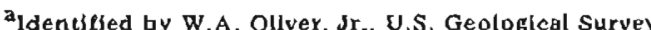

bidentified by J.T. Dutro, U.S. Geological Survey

$c_{\text {Reporled by Hickman and Craddock, } 1976}$

dIdenlifjed by D.L. Jones, U.S. Geological Survey.
} 


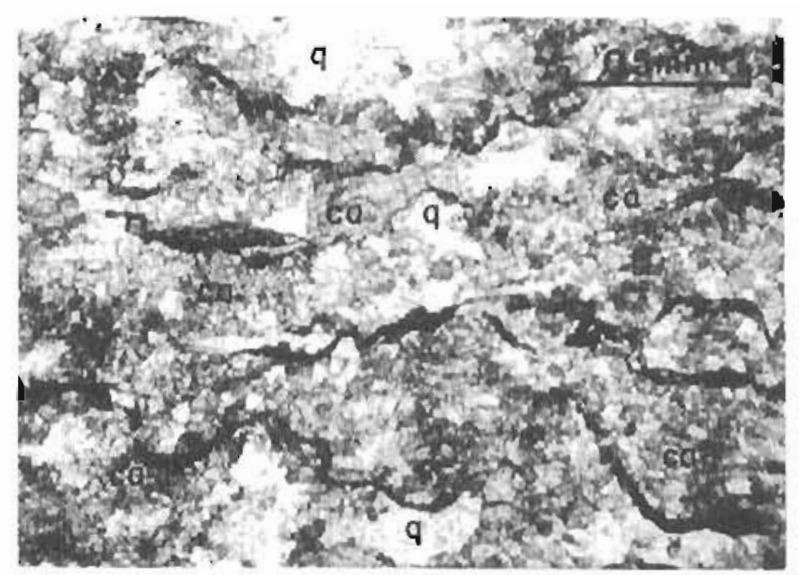

Figure 7. Photomicrograph of siliceous marble. Dark layers=carbonaceous material, cacalcite, $q \approx q u a r t z$. Plane light.

to phyllitic marble; the rock has a prominent cleavage where carbonaceous material and sericite are concentrated. Feldspar grains are present in trace amounts, and some grains identified as quartz in thin section may actually be untwinned feldspar.

The siliceous marble unit is in fault conlact with the Wyoming Hills sequence on the north and with the shate unit on the soulh. The unit is cul by mumerous diorite and gabbro intrusions and is overlain uncon. formably by the Paleocene Cantwell Formation.

\section{SLATE UNIT}

The slate unil is composed of dark-gray slate and fissile melasiltslone, metasandstone, and metaconglomerate which crop out in a northeast-trending band, 1.0 lo $4.0 \mathrm{~km}$ wide. across the southern part of the map area (pl. 1). The pasily eroded unit forms a topographic low. Near the Teklanika River the amount of lopographic relief and the width of the outcrop bett suggest a structural thickness of $2,400 \mathrm{~m}$ for the unit.

Slate and fissile metasiltstone are the doininant lithologies, but inetasandstone in beds up $1015 \mathrm{~cm}$ thick makes up about 10 percent of the unit. The rocks commonly display fine sedimentary laminations and crossbedding, and a plyyllitic sheen. Calcareous siltstone, silty marble, and granuje metaconglomerale are present as minor interbeds. The unit is commonly silicified around the margins of diorite and sabbro intrusions. A single metamorphic event has tightly folcled the unit and produced rarely observed isoclinal folds and moderately to sleeply dipping axial-plane clenvage. Cleavage is generally parallel to bedding, but in a few outcrops beding is crosscut by cleavage.

Subangular silt-size quartz grains compose slightly more than half of the slate and metasiltstone; sericite and carbonaceous inaterial make up the rest (fig. 8). Carbonaceous material either outlines small cross beds and layering in the rocks or, logether with sericilized argillacious material, is concentrated along cleavage surfaces.

Lightegray metasandstone was origlnally very fine to medium-prained volcaniclastic litharenite (Folk, 1971). It is composed of subangular clasts of quarlz (15-40 percent), feldspar ( 5.20 percent), felsite ( $15-55$ percent), chert (10-30 percent), siltstone (5-10 perceıt), plıyl. losilicate ( 3.10 percent), metamorphic clasts ( 0.10 percenl), carbonate $(0.5$ pereent), and carbonaceous maLerial $(0.5$ percent). These rocks generally display a less pervasive cataclastic planar tabric than the more fissile melasil tstone, but do have broken and stretched grains lying parallel to the cleavage; quartzose grains are partially annealed. Secondary sericite, chlorite, ano calcite (commonly present in crosscutting veinlets) are present in bulli slate and metasandstone.

The slate unit is in faull conlact with the siliceous marble unit on the north and wilh the Cantwell formation on the south. In the eastern part of the map area, the unic is inlruded by numerous diorite and gabbro intrusions. Along the Teklanikg River the unit is uncontormably overlain by the basal conglomerate of the Cantwell Formation.

\section{GABBRO}

Numerous northeast-trending intrusions of dark graygreen rine. to medium.grained gabloro and minor dlorite occur throughouc the siliceous marble unit and also cut the slate unit in the eastern part of the map area (pl. 1). The largest mapped body covers $1.0 \mathrm{~km}^{2}$, and many bodies are present which ane ton small to map.

The gabbro is composed of plagioclase ( $40-60$ percent), augite $(25-40$ perconl), serpentine and chlorite

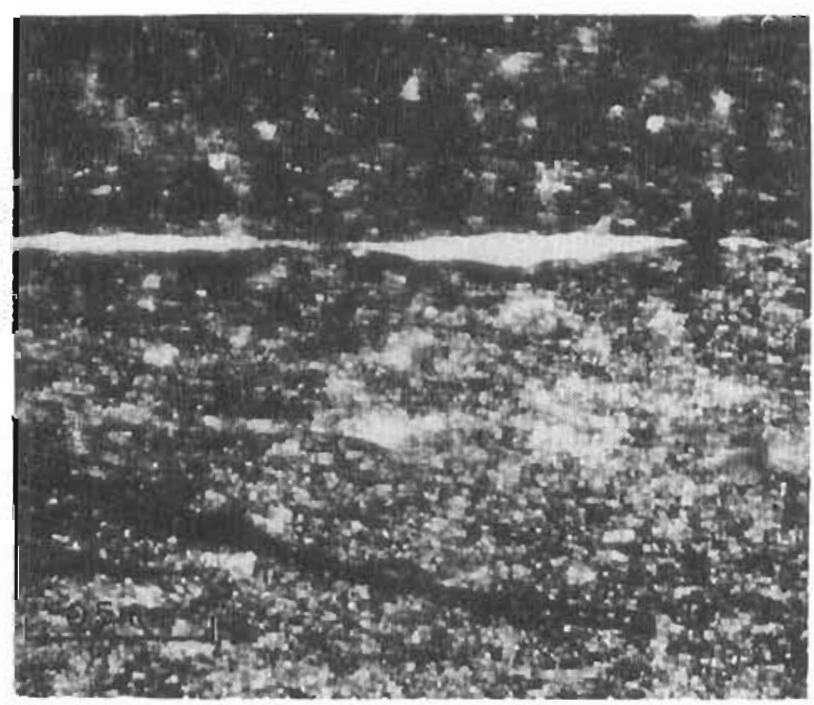

Figure 8. Photomicrograph of cross-bedded metasittstone of slate unit, Plane lighi. 
(10-20 percent), iddingsite (3-6 percent), quartz (0-7 percent), and trace amoluts of olivine, opaque minerais, epidote, and apatite (lig. 9). The gabbro has an ophitic texture, with subhedral plagioclase laths $0.2-2.0 \mathrm{~mm}$ long almost completely altered to day minerals. Anhedral augite crystals $0.3 .3 .0 \mathrm{~mm}$ across commonly in. clude and are surrounded by clusters of fibrous ser. pentine and masses of chlorite and occasionaly epidote. Iddingsite is generally intergrown with augite and very rarely contains a core of olivine. Quartz is inter. stitial and probably a late-stage magmatic derivative. Fine-grained gabbro exhibits cataclastic textures with augite commonly in shattered aggregates. Mediumgrained gabbro does not show cataclasis but rather has a hypidiomorphic granular texture.

\section{ARII, AND RELIRNAL CORRELATION}

All rocks in the southern terrane are considered to be pre-Cenozoic. Triassic eonodonts ate reported from 'mu' locality in the eastern part of the siliceous marble unit (Hickman and Cradelock, 1976; Hickman, pers. commun.), whereas a single specimen of Inoceramus found in rubble in the slate unit just east of the study area suggests a mid-Cretaceous age for that unit (table 2).

The marble and slate units are cut by numerous diorite and gabbro intrusions and are unconformably

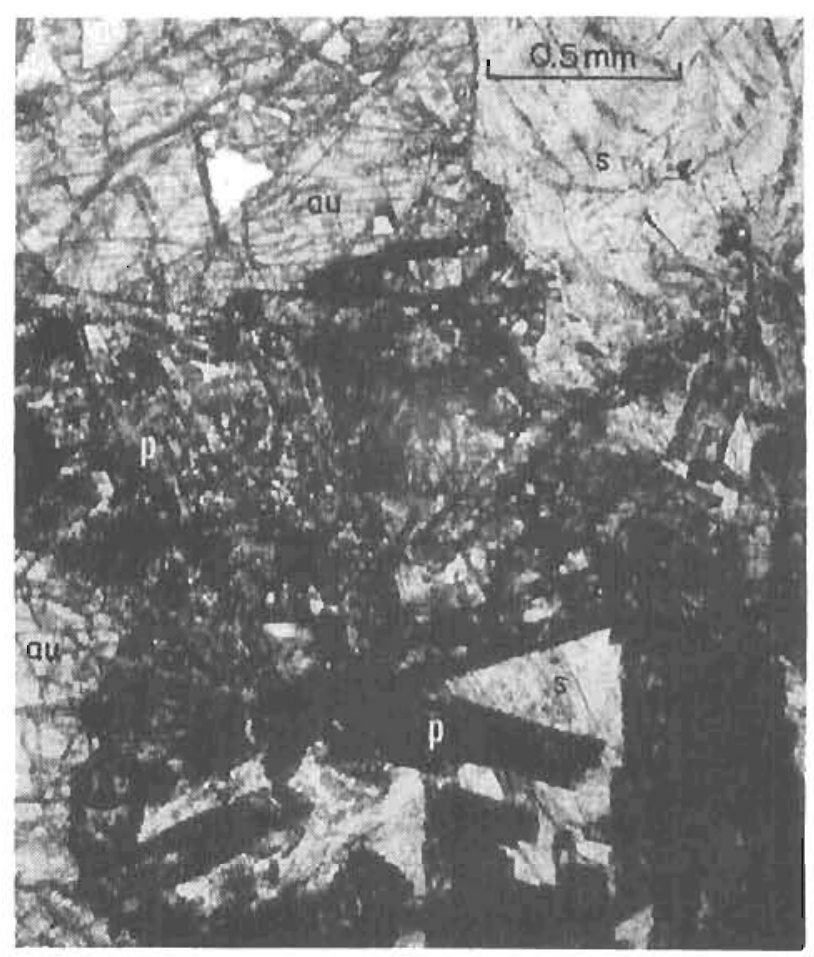

Figure y. Photomicrograph of gabbro in southern terrane: p=plagioclașe, au=augite, s=serpentine. Plane light. overlain by the Paleocene Cantwell Formation. Reed (1961) assigns the gabbro to the Triassic, but Hickman and Craddock (1976) favor a late Mesozoic age.

Correlation whith other areas is difficult because of the lithologic similarities between rocks of different ages. Hickman and Craddock (1976) consider the eastern part of the southem terrane to be part of an Upper Triassic series of argillite, limestone, and chertpebble conglomerate that continues for $30 \mathrm{~km}$ east of the map area. Undifferentiated Paleozoic argillite, slate, sandstone, chert, and fossil-bearing Devonian limestone, which are intruded by Triassic(?) gabbro and overlain by Triassic(?) metabasalt, are present $5.0 \mathrm{~km}$ south of the study area (Reed, 1961) (fig. 1). Thus, the southern terrane is part of an extensive series of weakly metamorphosed Paleozoic and Mesozoic rocks found throughout the Alaska Range south of the llines Creek strand of the Denali Cault system.

\section{STRUCTURE;}

Structures in the melamorphic terrances described in this study reflect 1) an early period of folding and dynamothermal inetamorphism, 2) a hater period of folding and dynamic metamorphism, 3) early Tertiary folding, and 4) late Cenozoic block cauting. The northern terrane exhibits structures from all tectonic episodes, whereas the southern terrane has structures from all but the second tectonic event.

\section{NORTHERN TERRANE}

The earliest structures preserved in the northem terrane are axial-plane foliation $\left(S_{1}\right)$ and rarely observed isoclinal folds $\left(\mathrm{F}_{1}\right)$. The isoclinal folds have large amplitude-to-wavelength ratios: amplitudes are as large as several tens of meters. The general altitude of the primary foliation $\left(S_{1}\right)$ is similar to most structural trends in the west-central Alaska Range, generally striking along an azimuth of $60^{\circ}$ and dipping moderately southeast or, less commonly, northwest ffig. 10).

Overprinted on the earliest preserved tectonic features are structures from a later dynamic metamorphic episode. Open to subisoclinal folds $\left(F_{2}\right)$ have wave. lengths that range from microscopic to several tens of meters, but small crenulations are most commonly observed (figs. 11 and 12). The lower limbs of $F_{2}$ antiforms and synforms are commonly thinned or sheared. F 2 folds occasionally obliterate earlier tectonic features in the Birch Creek Schist, but are less well developed in the Wyoming Hills sequence. As shown in figure 1.3. Fis fold axes trend approximately $S .55^{\circ} \mathrm{W}$. and plunge approximately $70^{\circ}$. A slip cleavage $\left(S_{2}\right)$ has formed parallel to $\mathrm{r}_{2}$ axial surfaces, along which a micaceous schistosity has developed locally and which has a gerstal aritnulh of $60^{\circ}$ and a gentle dip (fig. 14). 


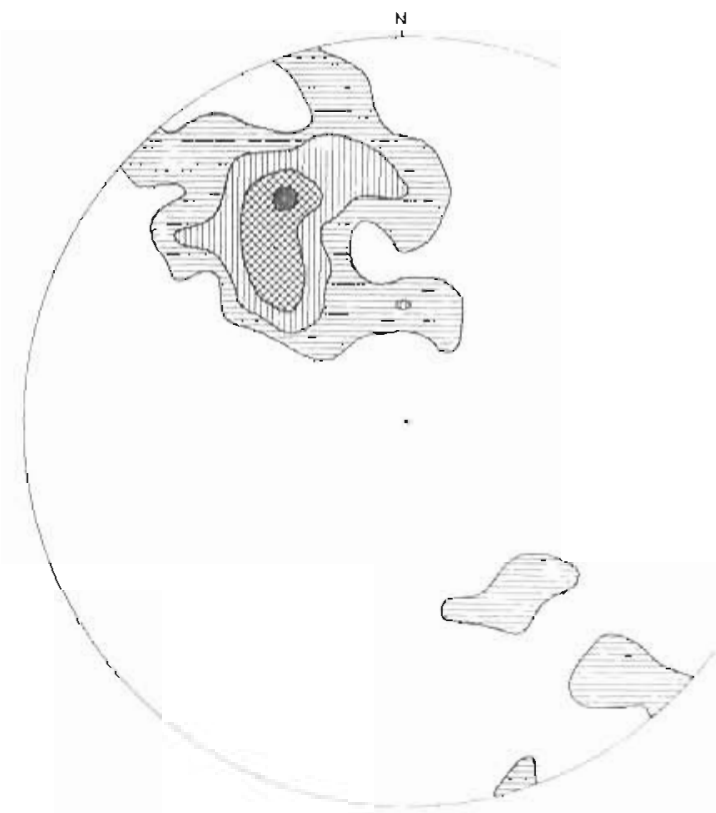

rigure 10. Lower hemisphere equal-ares plot of 216 poles to $S_{1}$ foliation sud cleavage in northern terrane. Contour interval at 2, 4,6, and 8 percent per 1-percenl. area.

\section{SOUTHERN TERRANE}

In the southern terrane only a single period of folding and metamorphism has affected the rocks (fig. 15). Scattered lold axes have a gently dipping southwest trend (iig. 16). Cleavage orientation in rocks of the southern terrane (fig. 17) is similar to the $\mathrm{S}_{1}$ foliation orieniation in the northern terrane (fig. 10) and is different from $S_{2}$ cleavage in the northern terrane (fig. 14), possibly indicating that an early strong regional metamorphic event produced structures in both terranes. The absence of evidence for a second episode of folding and metamorphism in the southern terrane suggests that the two terranes were separated far enough so that only the northern terrane was affected by the second, weaker metamorphic event.

\section{CENO\%OIC STRUCTURLS}

Early Cenozoic folding and late Cenozolc block laulting affected both metamorphic terranes and the overlying Paleocene Cantwell Formation (pl. 1) (Gil. bert, 1975; Gilbert and Redman, 1975). Fold axes shown in plate 1 refiect early Cenoznic folding. The vague girdle suggested by $\mathbf{S}$ surfaces in both terranes (figs. 10,14 , and 17 ) most likely reflects northeast..

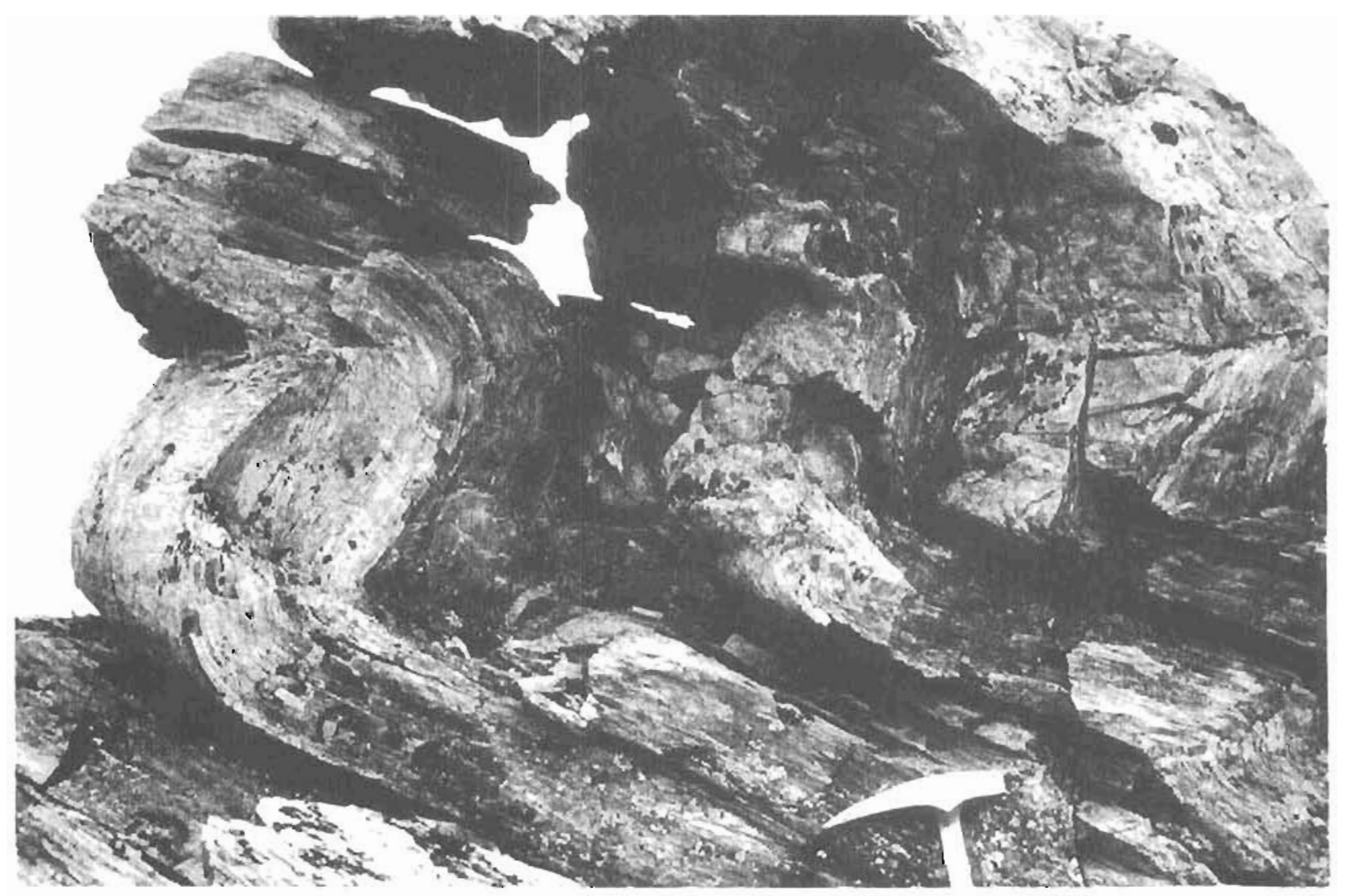

Figure 11. Folded Birch Creek Schist, showing prominent. $F_{2}$ folds. 
trending open to ciosed folds formed at this time (Gilbert, 1975).

\section{HINES CREEK FAULT}

Alihough the Hines Creek fault projects from the cast into the Wyoming Hills fault in the study area, the Hines Creek fault in this report is considered to be the tectonic contact between the two dissimilar meta. morphic basement ierranes. The fault probably merges with the Wyoming Hills fault near the Teklanika River in the northenst part of the map area (pl. 1).

West of the East Fork Toklat River, the Hines Creek fault dips about $45^{\circ}$ north and consists of a zone about $150 \mathrm{~m}$ wide that contains slivers from both the northern and southern terranes (fig. 18). This portion of the faut shows no evidence of Cenozoic movenent. East of the East Fork Toklat River, the Hines Creek faull has apparently been rejuvenated as a high-angle fault during Cenozoic block faulting (Gilbert. 1975).

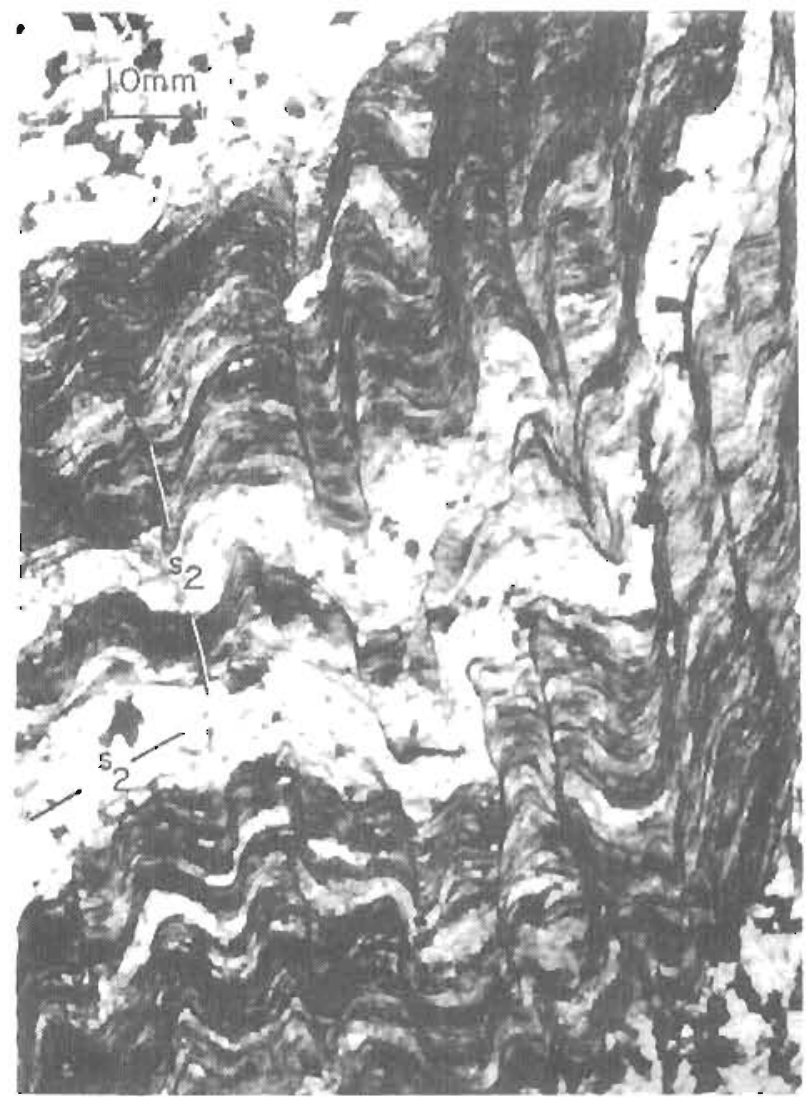

rigure $1 \%$. Photomicrograph of sericite-ģuartz phyllite of Wyoming Hills sequence showing $\mathrm{S}_{1}$ foliation and crosscutting $S_{2}$ cleavage. Plane light.

\section{CONCLUSION}

In the area of the Toklat and Teklanika rivers, the Hines Creek fault juxtaposes two distinct metamorphic texanes. The northern terrane was forned by multiple

$\stackrel{N}{N}$
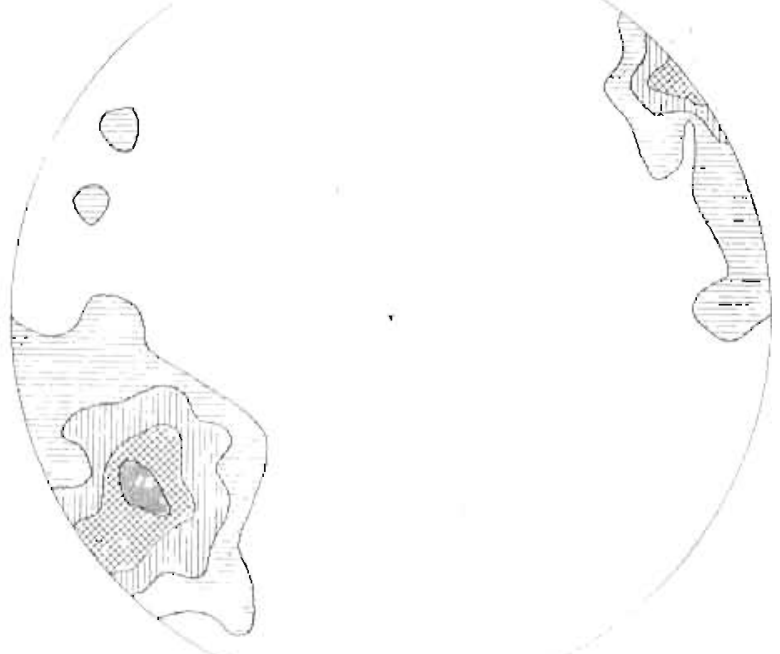

Figuse 13. Lower hemisphere equal-area plot of 155 $F_{0}$ fold axes in northern terrane. Contour interval at $2,4,6$, and 8 percent per 1 -percent area.
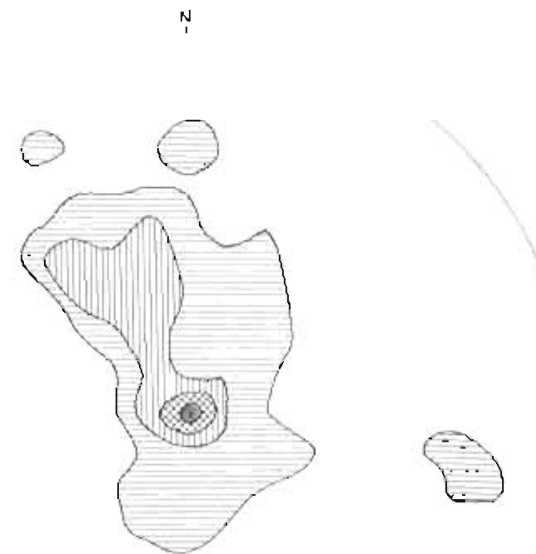

Figure 14. Lower hemisphere equal-area plot of 14$]$ poles ho $S_{2}$ clevvage in northern terrane. Contour interval at 2, 4, 6, and 8 percent per 1-percent area. 


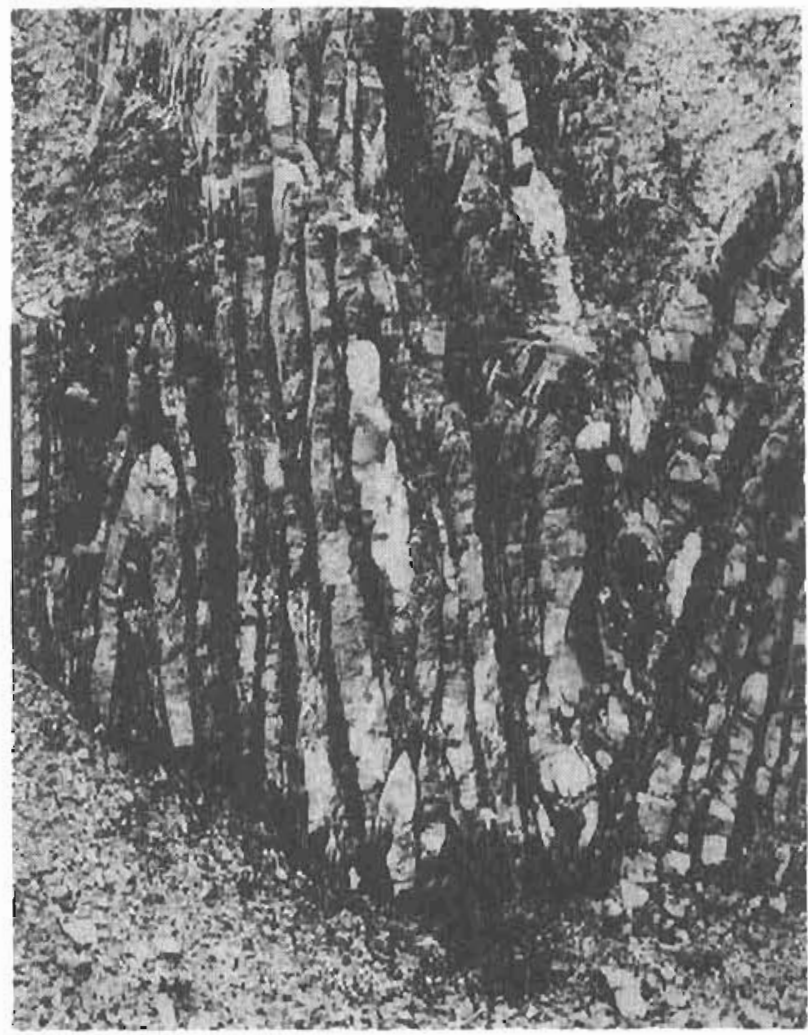

Figure 15. Folds in siliceous marble unit on east side of Wyaming Hills.

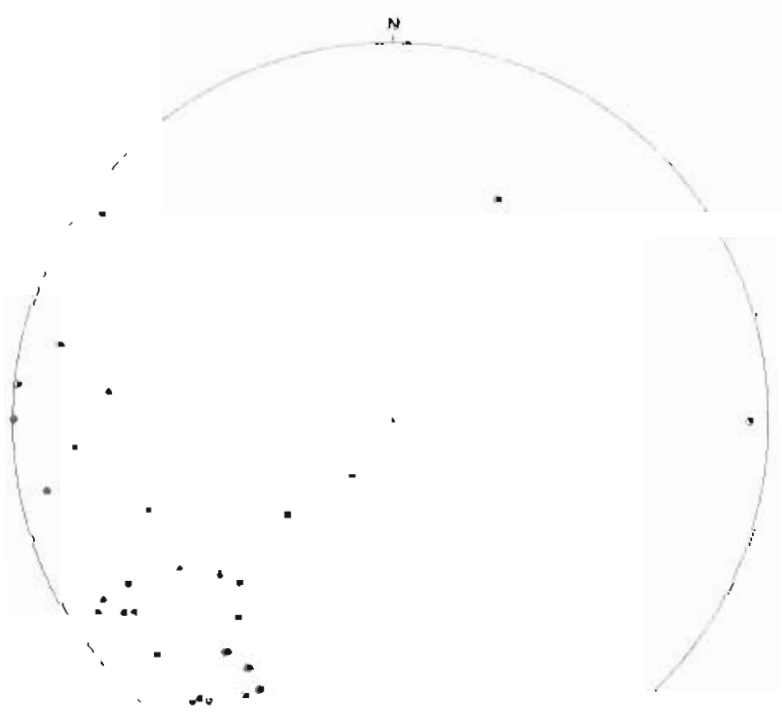

Figure 16. Lower hemisphere equal-area plot of 30 fold axes in sumblorn tartimu.

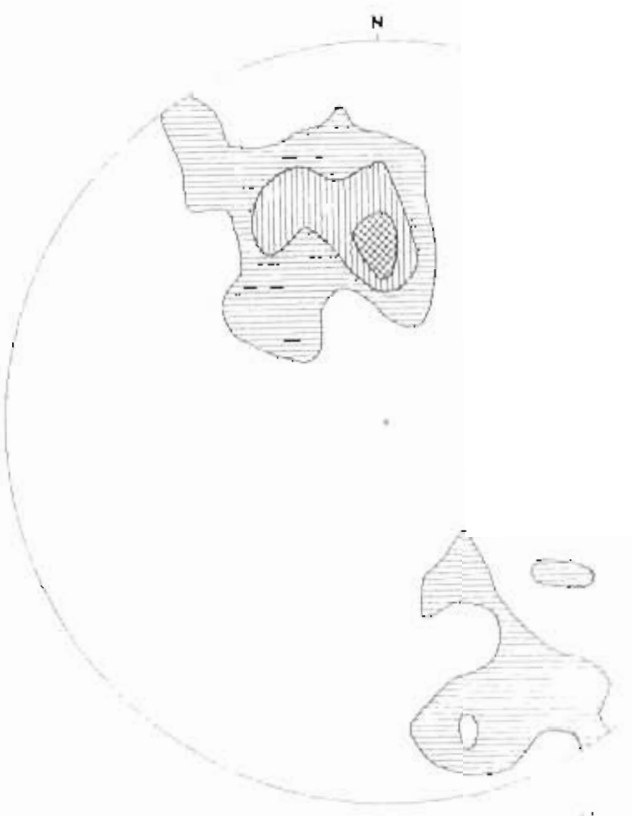

Figure 17. Lower hemisphere nusk-srea plot of 181 poles to cleavage in southern terrane. Contour in terval at 2, 4, and 6 percent per 1-percent area.

deformation of quartz-rich predominanty clastse sedimentary rocks. Moreover, correlation of metavoicanic parts of the Wyoming Hills sequence with nearby coeval metavolcanic sequences suggests that mid-Paleozoic andesitic volcanism affected at least $5,000 \mathrm{~km}^{2}$ in central Alaska.

The weakly metamorphosed Mesozoic rocks of the southern terrane probabiy represent land-derived, marine clastic and pelagic sediments. Gabbro intrusions, which are characteristic of this terrane, together with equivalent mafic extrusive rocks, suggest tectonic instability in latest Mesozoic time. By Cenozoic time, however, both terranes were juxtaposed along the Hines Creek strand of the Denali fault system.

\section{ACKNOWLEDGMFNTS}

The authors wish to thank the National Park Service, in particular Daniel Kuehn and Vernon Ruesch, super. intendents of Mt. McKinley National Park, for their cooperation during our field st,udies.

The paleontelogical information given by W. A. OJiver, J.T: Dutro, and D.L. Jones of the U.S. Geological Surry is greatly appreciated.

In addition, special thanks are due to John E. Decker. Florence R. Weber, Thomas $K$. Bundtzen, Thomas E. Smits, and Richard D. Reger for their he!pful criticism and review of the manuscript, and to Richard Jirik and John W. Buza for their assistance in the field. 


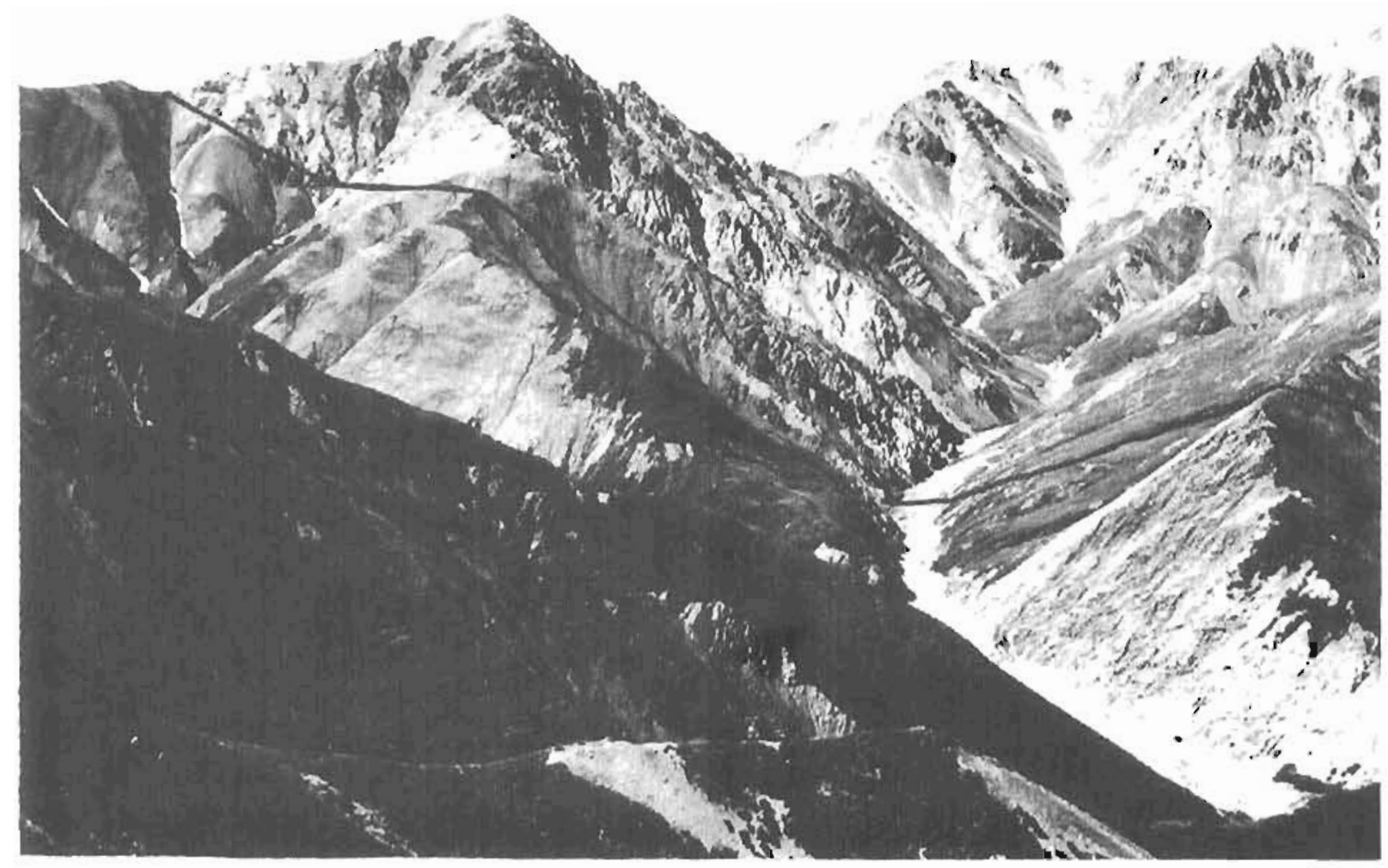

Figure 18. Looking wesh at trace of Hines Creek Faull (blnck line) in Wyoming Hills.

\section{REIERENCLS CITED}

Brooks, A.H., 1911, The Mount McKinley region, Alaska: U.8. Geol. Survey Prof. Paper 70, 243 p.

Bundtzen, T.K., 1976, Progress report, geology and mineral deposits of the Kantishna Hills: Alaska Div. Geol. and Geophys. Surveys Open-File Repl. 98 , $80 \mathrm{p}$.

Capps, S.R., 1919, The Kantishna region, Alaska: U.S. Geol. Survey Bull. 687, 118 p.

1932, The eastern portion of Mount McKinley National Park: U.S. Geol. Survey Bull. 836-D, p. 219300.

1940. Geolony of the Alask a Raitroad region: U.S. Geol Survey Bull, 907, 201 p.

Folk, R.L., 1974, Petrology of sedimentiry rocks: Hemphill Publishing Company, Austin, Texas, $182 \mathrm{p}$.

Gilbert, W.G., 1975, Outline of tectonic history of west-central Alaska Range: Geol. Soc. Americs Abs. with Programs, Cordilleran Section, p. 320.

1977, General geology and geochemistry of the Healy D- 1 and southern Fairbanks $\mathrm{A}-1$ quadrangles and vicinity: Alaska Div. Geol. and Geophys. Surveys Open-File Rept. 105, 12 o., 2 maps.

Gilbert, W.G., and Rednam, Earl, 1975, Geologic map and structure sections of Healy C-6 quadrangle. Alaska: Alaska Div. Geol. and Geophys. Surveys Open-File Rept. 80,1 p., map.
Gilbert, W.G., Ferrell, V.M., and Turner, D.L., 1976, The Teklanika Formation-A new Paleocene volcanic formation in the central Alaska Range: Alaska Div. Geol, and Geophys. Surveys Geol. Repl, 47, $16 \mathrm{p}$.

Hickman, R.G., 1974, Structural geology and stratigraphy along a segment of the Denali fault system, central Alaska Range, Alaska: Unpub. Ph.D. thesis, Madison, University of Wisconsin, $276 \mathrm{p}$.

Hickman, R.G., and Cracilock, Campbell, 1976. Alaska Div. Geol. and Geophys. Surveys Open-File Rept 95,3 maps.

King, P.B. (compiler), 1968. Tectonic map of North America, U.S. Geol. Survey map.

Morrison, D.A., 1964, Geology and ore deposits of Kantishng and vicinity, Kantishna districh. Alaska: Unpub, M.S. thesis, Fairbanks, Univerșity of $\Lambda$ laska, $109 \mathrm{p}$.

Redman, Eart, 1974, Geology of the Wyoming Hills. Mount McKinley National Park, Alaska: Unpub. M.S. thesis, Fairbanks, University of Alaska, $61 \mathrm{p}$.

Reed, J.C., Jr, 1961. Geology of the Mount Mckinley quadrangle. Alaska: U.S. Geol. Survey Bull. $1108-\mathrm{A}$. $36 \mathrm{p}$.

Wahrhaftig, Clyde, 1968, Schists of the central Alastea Range: U.S. Geol. Survey Bull. 1254-E, $22 \mathrm{p}$.

Wegner, W.W., 1972, The Dessli inull (Hines Creek strand) in the norheastern Momm Mckinley National Park, Alaska: Unpuh. M.S. thesis, Madison, University of Wisconsin, $7.1 \mathrm{p}$. 